\title{
Correlates Of Recidivism Among Released Prisoners: A Study of Kakamega County, Kenya
}

\author{
Dr. Evans M. Oruta \\ Lecturer, Department of Criminology \& Social Work, \\ Masinde Muliro University of Science and Technology (MMUST). \\ Prof. Dr. Willem FM Luyt \\ Department of Correctional Management \\ University of South Africa (UNISA)
}

\begin{abstract}
Released prisoners in Kenya have a 75\% likelihood of committing another crime and a 50\% probability of going to jail two years after their discharge from prison custody. From the trend of recidivism in Kenya, there are a staggeringly high number of offenders being incarcerated and eventually released back to the community, and the high risk of re-arrest and re-incarceration is a concern for policymakers, criminologists and correctional managers.

This study examined the influence of offender characteristics, offender reintegration and community perception and attitude regarding recidivism in Kakamega County, Kenya. The study adopted a survey research design. Findings reveal a statistically significant relationship between offender characteristics and recidivism. In addition, offender reintegration and community perception and attitude towards offenders greatly influence recidivism.

From the study, it is recommended that the government provide correctional officers with the required resources to use the actuarial risk assessment model. The model is applied to the released offenders to predict the future probability of recidivism. In addition, it is recommended that the government and the various correctional stakeholders come up with an integrated approach that specifically targets successful re-entry of offenders upon release from prison. Finally, it is recommended that the government develop programmes targeting awareness of the community members to desist from stigmatising ex-offenders.
\end{abstract}

Key terms: Correlates, Recidivism, Prisoners, Kenya

DOI: $10.7176 / \mathrm{JLPG} / 109-07$

Publication date:May $31^{\text {st }} 2021$

\subsection{Introduction}

The term recidivism originated from the Latin language 'recidivus' meaning 'falling back' (Maltz, 2001: 54). One interpretation of this is that a first-time offender who commits a subsequent crime is a recidivist, but the literature shows that various other definitions for recidivism are used. Maltz, (2001: 1) looking at recidivism in a criminal justice perspective defines it as the exposure of a person to criminal conduct after an arrest, probation and possibly correction of a previous offence. Recidivism has been described in different ways like a return to custody for any cause, even procedural breaches (Verbrugge, Nunes, Johnson \& Taylor, 2002: 2). Others see it as re-arrest (Benda, 2005:326), re-incarceration (Law, 2015: 465).

The International Centre for Prison Studies estimates that as of August 2016, over 11 million people were held in prison custody throughout the world (Walmsley, 2016: 2). According to Owens (2009: 326) prisoners account for 5 percent of the world population. In spite of interventions by corrections to enable offenders to live crimefree lives after a period of incarceration, ex-convicts been exposed to the criminal justice system through either being re-arrested, re-convicted or re-incarcerated again and again, suggesting that the treatments and support systems they receive in and out of prison are either ineffective or non-existent. The act of offenders encountering the criminal justice system after their release, whether through technical violations or new offences finds expression in the concept of recidivism (Duwe, 2010: 57).

Statistics throughout the globe suggest that most prisoners coming out of prison are likely to be re-sentenced within three years of their release. (Freeman, 2003: 2) avers that almost 80 percent of prisoners are likely to be 
rearrested within a decade of being free. (Hassin, 1989: 46) in his study suggest that rearrests around the world may occur within the first year of release if no support is given to the offender. High recurrence rates mean more violence, more victims, and more criminal justice system stress. Recidivism is a technical term which, when loosely understood, bypasses the major problem it faces, the problem of continuity of criminal behaviour.

Released prisoners in Kenya have a seventy-five percent likelihood of committing another crime and a fifty percent probability of going to jail two years after their discharge from prison custody (Oruta, Omosa \& Lumumba, 2017: 101), which compounds the high prison population problem and overcrowding. A large number of inmates is exacerbated by an increasing number of re-offenders being imprisoned. The incredibly high recidivism rate has enormous costs of public safety and money spent on prosecuting, charging and incarcerating re-offenders.

\subsection{The research problem}

The Kenya Prisons Service is mandated by the Prisons Act Chapter 90 Laws of Kenya (Republic of Kenya, 2012: 8), to handle rehabilitation and transformation of prisoners by learning, counseling education and career programmes. One of the core functions of the Kenya Prisons Service is rehabilitation and reformation of prisoners for social re-integration. The Probation Service in Kenya is charged with the reintegration and resettlement of offenders released from prisons through the aftercare services provided under the Probation of Offenders Act 11 of 2017.

Despite the resources spent by the State Department of Corrections, which comprises of the Kenya Prisons Service and the Probation Service to rehabilitate, reform and reintegrate offenders, a high rate of recidivism has been recorded in the country. According to the Kenya National Bureau of Statistics Report (Republic of Kenya, 2019: 277) in the year 2018, there were 16987 recidivists in prisons out of 53765 average daily prison population representing 35,59 percent. This cyclic movement of offenders to prisons from the community and back to prisons after release will without any doubt contribute enormously to the growth of the prison population and strain the allocated resources. In addition, there will be increased crime rates in society.

Little has been documented about an integrated offender management process in Kenya. The transitional challenges offenders face upon release from prisons have not been adequately addressed. Thus, it becomes imperative through sound research to find out the correlates of recidivism among released prisoners by specifically establishing the role of prisoner reintegration on recidivism, the relationship between offender characteristics and recidivism, and the influence of the community perception and attitude on recidivism. This will adequately address the transitional challenges that offenders face upon release from prisons that influence their re-offending behaviour in addition to developing an integrated approach towards the offender management process.

\subsection{Research aim and objective}

Examine the relationship between offender characteristics and recidivism in Kakamega County

\subsection{Research methodology}

The study on "the correlates of recidivism among released offenders in Kakamega County" has been conducted by survey research design. This design is usually based upon samples whereby instead of directly studying whole populations, surveys typically collect evidence from a small sample of people selected from the population (Jupp, 2002:34). This design aids the researcher in collecting original data to describe a population that is too large to observe directly.

The study population for this study comprises of recidivists serving custodial sentences in three Penal Institutions within Kakamega County, Western Region in Kenya.

Offenders incarcerated in Kakamega Male, Kakamega Female and Shikusa Government of Kenya Prisons constitute the unit of analysis. In addition, correctional officers (probation officers and prison officers) based within Kakamega County are interviewed.

The study has both quantitative and qualitative data. Therefore, both descriptive and inferential statistics are used to analyse the data. Once the questionnaires were received they were coded and edited for completeness and consistency. After data from the questionnaires were edited, cleaned and coded, it was analysed. 


\subsection{Review of Related Literature}

According to (Maltz, 2001: 1) recidivism originated from the Latin word "recidere" which can be interpreted as "to fall back." Despite current public outrage regarding career criminals, evidence has shown that recidivism is not a fresh thing and dates back to Warner's study in Massachusetts in 1923, on the success or failure of parolees.

Williams (1979: 15) noted that in order to form a recidivism scale, three issues were to be resolved - What criminal justice system occurrence is to be called a recidivistic, a re-arrest, a re-prosecution, or a re-conviction? How can the gravity of the offence that gave rise to the occurrence of the offence be taken into account? How can the frequency of the event be taken into account? A study by Frederique (2005: 10) reports that people completing longer sentences are more likely to recidivate,

unlike those serving shorter sentences. The question arises as to whether the sentence actually prohibits offenders from offending as it is common practice for incarcerated persons who spend time in prison to re-offend as noted in Maltz (1984: 11). It compromises the position of institutions that fight crime. The intention of this chapter is to address the idea of recidivism in relation to offender characteristics.

\subsubsection{The role of offender characteristics and recidivism}

This chapter addresses the influence of gender, age at the time of imprisonment, educational level, employment status, accommodation, romantic relationships, children, peer relationships, prior criminal records, criminal record and alcohol consumption on recidivism.

\subsubsection{Gender and recidivism}

Benda's research (2005: 328) of 300 women and 300 male boot camp students found that there were significant gender gaps in group tenure predictors of violent recidivism over a 5-year follow-up span (Benda, 2005: 331). Cox Proportional Risk Models (Benda 2005: 332) indicate that residential living, childhood experiences, past childhood abuse, drug sales, pressure, anxiety, distress, suicidal thinking, and suicide are better beneficial predictors for recidivism for both men and women. Because of violent social networks, weapons-bearing, alcohol abuse, and hostile emotions, men are more likely to go to jail. Employment, happiness in the family takes more room for men than for women, while the number of children and marriages in society is more important for women (Benda, 2005: 233).

\subsubsection{Age at the time of incarceration}

Incarceration, especially at a young age, may contribute to an accumulation of life-long disadvantages with severely limited future opportunities (Sampson \& Laub, 1993: 19; Western, Kling, \& Weinman, 2001: 413). Since imprisonment is so widespread among Black men with low levels of education, the effect on their individual incomes further raises wage inequality at the aggregate level (Western, 2002: 529).

\subsubsection{Educational level and recidivism}

Review by Petersilia (2003: 71) and Travis, Solomon and Waul (2001: 65) show that the majority of returned prisoners are less trained than the general population. Recidivism as a social problem cannot be reduced without prison-based intervention to reduce the criminogenic needs of offenders. Most prisoners leaving jails lack job skills and experience and are less likely to receive the necessary social support (Lynch \& Sabol, 2001: 31). As a result, returning prisoners are less prepared for post-release and will receive less assistance and encouragement to succeed (Petersilia, 2003: 60)

\subsubsection{Employment and recidivism}

Lack of work is a common factor in breaches of recidivism of probation and rehabilitation, and having a criminal background limits job opportunities and lowers wages (Holzer, 2001: 91). Labor statistics in New York State indicate that 89 percent of formerly imprisoned persons who breach the provisions of their probation or parole were unemployed at the time of the violation (Mukamal, 2000: 441). Further research suggests that up to 60 percent of former prisoners do not work 1 year after release (Nightingale \& Watts, 1996: 27). According to a study carried out by Bushway and Reuter (as cited in Solomon, 2004: 152), one in three inmates reported becoming unemployed since entering the State prison and less than half had a job lined up before being discharged.

Researchers also indicated that former inmates get jobs upon their release usually find jobs by friends or family (La Vigne et al., 2004: 77; Travis, 2005: 90). While projects aimed at helping ex-offenders with jobs have seen 
some degree of success, these services have limitations in terms of ability and regional scope (Solomon et al., 2004: 309).

\subsubsection{Housing and recidivism}

In the United States of America, the bulk of discharged prisoners reside near their family members. Approximately three-quarters of Chicago released inmates expected to stay with the family in one analysis of the Urban Institute, and an even greater 88 percent were staying with the family 4 to 8 months later (La Vigne et al., 2004: 39). This is not always an obvious or possible choice, as family members may have been victimised, or otherwise harmed by a returning person. Women offenders experience high rates of abuse and victimization, regularly at the hands of household members, both in childhood and adulthood (Chesney-Lind, 2002: 88; Harlow, 1999: 341; Richie, 2001: 380).

Ex-offenders who have been accused of sexual offenses face additional limits on housing safety. In the United States of America, 47 States and the Federal Government are enforcing Megan's Amendment law which allows people guilty of sexual offenses to enroll.

\subsubsection{Parenthood, social relationships, and recidivism}

In the United States of America, State and Federal jails, well under half of the inmates have minor children; twothirds of the women and half of the men in prison were parents (Glaze \& Maruschak, 2008: 126). Research by Glaze and Maruschak (2008: 117) found that the child's mother was 88 percent the primary caregiver of the offspring of the incarcerated parents. On the other side, just 37 percent of those with imprisoned moms stay with their fathers; 45 percent of those children are most probable to live with their grandparents and 23 percent with other families.

Knowing the peer system and the probability of relapse through criminogenic social networks, especially between male offenders, is the subject of much criminological study (Scott, 2004: 342; Warr, 1998: 204). Those ex-offenders who revive behavioural patterns from pre-incarceration, such as spending time with old friends, searching for easy money, participating in side-relations and one-night stands, were more prone to re-offend than those who socially isolated themselves and participated in more pro-social behaviour or intimacy behaviours (Seal, Eldrige, Kacanek, Binson \& Macgowan, 2007: 2398). Nevertheless, for some criminals, when released from prison, the possibility of entering criminal networks can seem to be one of their favourite options, even if they realise that this can be self-defeating (Scott, 2004: 74).

\subsubsection{Prior criminal history}

Prior illegitimate record, including the aggregate of preceding arrests, prosecutions and the duration of the first crime or sentence, has not only been reliably related to recidivism in empirical studies but has also proven to be a strong correlation to recidivism. Pritchard (1979:27) analysed 71 recidivism trials, including 177 separate surveys of criminals, and found that the prevalence and amount of previous adult convictions contributed to recidivism in 99 of the 116 cases in which it was studied, while the age at first indictment was linked to recidivism in 77 of the 95 studies which examined its effect on recidivism. In contrast, Burgoyne (1979:96) found that the number of former convictions and age at first arrest was the greatest predictor for recidivism in a study of criminals discharged from Victorian jails between January 1972 and December 1973. Furthermore, a higher rate of recidivism was observed for those criminals with a higher number of prior convictions and those whose first arrest came at an early age.

Similar results were recorded if the previous record of the crime was specified in terms of the number of past adult arrests (Bureau of Justice Statistics, 1989: 13). The study found that the more severe a pre-arrest inmate released, the lower his or her possible rate of recidivism. Of those released inmates with only one previous adult conviction, 38.1 percent were re-arrested during the three-year follow-up cycle relative with 82.2 percent of those released inmates with 16 or more prior adult convictions. The percentage of recent adult convictions was a strong predictor for recidivism even when the age of release from prison, sex and race and the number of previous incarcerations (Illinois Criminal Justice Information Authority, 1985: 29) was taken into account.

Empirical studies have found that prisoners who have a past term of imprisonment (United States Bureau of Justice Statistics 1984:22, 1989:51; Burgoyne 1979:39), have been state-owned or have received a number of concurrent parole orders (Burgoyne 1979:39) have a high level of recidivism, indicating that existing punishment and criminal record are also a source of recidivism. 
Throughout his dissertation on "Seeing Class Self," Cooley (1998: 490) explains that the idea of self-concept is a function of other perceptions towards the person concerned. If others deal with an individual as if he were particular characteristics, then a self-fulfilling prophecy is created. So if other people think that we are such an individual (smart, educated, nice, respectful and criminal), then they act accordingly. Our self-concept and behaviour are therefore formed by a tag. The use of the tag on offenders as "criminals" or "evil" people was meant to prevent violence but, sadly, the unanticipated effect of the mark is the continuation of the offense. Therefore, the more negatively branded an individual, the greater the predisposition to commit more crime. (Akers, 1997: 40).

It is important to note that these marks reflect what Braithwaite (1989: 159) considered disintegrative guilt because they were directed at stigmatizing or condemning the individual as an undesirable member of society. The perception of detention prohibits inmates from having multiple resources and opportunities to avoid reoffending (Malott \& Fromader, 2010: 521). Background checks are the gate-keeping tool used by companies to weed out candidates with or without criminal records. According to Petersilia (2003: 87), employment opportunities legally restricted for ex-offenders in America include childcare, schooling, safety, nursing, and home health care. She states that, in a State like California, ex-offenders are legally prohibited from certain occupations such as business, real estate, pharmacy, counseling, physical therapy, and health.

In a specified follow-up period, a criminal with prior contact with law enforcement officers does not become completely indistinguishable from those without prior contact with respect to the risk of offending (Kurlychek et al., 2006: 309). The more a person lives a crime-free life, the more he or she understands the value of criminal isolation. In contrast, criminals with strong criminogenic conditions re-offend more than those who try to avoid fresh crimes. Notwithstanding that, it is an open secret that it is difficult for people with a criminal history to secure employment.

\subsubsection{Recidivism in Kenya}

Article 28 of the Constitution of Kenya provides that every person has inherent dignity and the right to have that dignity respected and protected (Republic of Kenya, 2010: 25). In addition, Article 51 of the Kenyan Constitution provides that a person who is arrested, held in custody or imprisoned under the law shall maintain all the privileges and basic freedoms set out in the Bill of Rights, except to the degree that any specific right or fundamental liberty is explicitly inconsistent with the condition that the person is detained, held in custody or imprisoned. (Republic of Kenya, 2010: 36). The law further provides for the humane treatment of prisoners in line with the United Nations Standard Minimum Rules for the Treatment of Prisoners to which Kenya is a signatory. These legal provisions are entrenched in the Prisons Act (Chapter 90) laws of Kenya which emphasizes on humane treatment of offenders.

Released prisoners in Kenya have a seventy-five percent risk of committing another crime and a fifty percent probability of going to jail two years following their release from prison (Oruta, Omosa \& Lumumba, 2017:101). This phenomenon compounds the high prison population problem and overcrowding. The extremely high rate of recidivism has immense costs in terms of public safety and money spent on investigating, punishing and incarcerating re-offenders.

According to the Kenya National Bureau of Statistics Report (Republic of Kenya, 2019: 277) in the year 2018, there were 16987 recidivists in prisons out of 53765 average daily prison population representing 35,59 percent. In the year 2017, there were 16371 male prisoners and 1453 female prisoners with a previous conviction record totaling 17826 recidivists in prisons (Kenya National Bureau of Statistics, 2018:267). Additionally, the Kenya National Bureau of Statistics Report (Republic of Kenya, 2017:272) indicates that in the year 2016, there were 14724 recidivists out of 57000 total prison population representing 25,8 percent.

The next sections highlight the various correctional institutions and programmes in Kenya that take part in offender management including recidivists.

\subsubsection{Theoretical underpinnings of recidivism}

Recidivism is not explained by a single theory (Ryan \& Yang, 2005: 186). Correlations in relapsed offenders' recidivism and criminal activity are the product of a complex phenomenon. Strain theories and labeling theory are used in the study. One model, positive psychology is also used. These theories and model explain the relationship between socio-economic, human and environmental factors and recidivism. 


\subsubsection{Strain theories}

In this category of strain theories, two theories are discussed, namely: the General Strain Theory by Robert Agnew and the Strain Theory by Robert K. Merton. In 1992, Robert Agnew developed the General Strain Theory, partly as a response to the disadvantages and limitations of older strain models that were almost abandoned in the latter part of the 20th century (Agnew, Brezina, Wright, \& Cullen, 2002: 334; Slocum, Simpson, \& Smith, 2005: 468). Nevertheless, Agnew's strain model has origins that could probably trace back to the turn of the 19th century, when Emile Durkheim published his notorious novel, "Suicide" (Durkheim, 1897: 597).

Durkheim's emphasis on self-destruction and suicide led him to the idea of anomie which he defined as a state of normality that could lead to a lack of norms or guidelines for people's behaviour (Durkheim, 1897: 693). As with Agnew's general theory of strain, Durkheim's concept of anomie is also quite direct, especially when looking at his explanation of anomie. Throughout his study of suicide, Durkheim speaks also about the influence of crises, and how crises reflect dislocations and irregularity throughout one's existing existence, forcing people into unusual or unknown circumstances (Durkheim, 1897: 699). Being in this state without rules or expectations as to what is appropriate or feasible can cause people to lose understanding and lead them to a state of dissatisfaction and torment triggered by their pursuit of unattainable goals and capabilities (Akers \& Sellers, 2004: 317).

\subsubsection{The Labeling theory}

Labeling theory is founded on the premise that some members of society are capable of building and applying attributes to other members of the same society (Becker, 1963: 207). According to research, the application of a negative label by one social group to another produces another and thereby stigmatises the individual or group to which the tag has been applied and is considered beyond traditional society (Akers \& Sellers, 2009: 211; Becker, 1963: 201). Becker (1963: 201), the founder of labeling theory, stated that deviant behaviour only exists after members of society have defined it as such.

Labeling theory falls within the symbolic interactionist paradigm which assumes that one's identity and selfconcept are continuously determined by interactions with others and thus exist only on the basis of social interaction (Akers \& Sellers, 2009:169). This can, therefore, be concluded that those individuals who are negatively branded would incorporate this tag into their view of themselves. Goffman (1963: 73) assumed that those who were branded would not act in ways that undermined the tag, but rather display actions that validated it. Akers and Sellers (2009: 188) say a person will face humiliation and shame once it has been branded. It is these feelings that will provide motivation to engage in further deviant acts for labeled individuals. Furthermore, once labeled, the label recipients adopt the characteristics generated as part of their primary identity and live in ways that confirm the stereotypes attached to the label, thereby confirming their authenticity to the individual.

\subsection{Study Findings}

Study findings are presented in this section;

\subsubsection{Relationship between offender characteristics and recidivism}

The first specific objective of the study seeks to investigate the relationship between offender characteristics and recidivism among released prisoners in Kakamega County. Individual characteristics of respondents that are of interest to the study include

- Gender;

- Age;

- Offence type;

- Number of convictions;

- The period between incarceration;

- Type of prison sentence; and

- $\quad$ Drug use prior to imprisonment

The following null hypotheses are formulated;

Ho1: Offender characteristics do not have a significant influence on recidivism

$\mathrm{H}_{1} 1$ : Offender characteristics have a significant influence on recidivism 
Study data relating to individual characteristics and recidivism are subjected to the Pearson Product Moment Correlation Coefficient and findings are presented in table 2.

Table 2: Relationship between offender characteristics and recidivism

\begin{tabular}{llcc}
\hline & & $\begin{array}{c}\text { Personal } \\
\text { Characteristics }\end{array}$ & Recidivism \\
Personal & Pearson Correlation & 1 \\
Characteristics & Sig. (2-tailed) & & \\
& $\mathrm{N}$ & 329 & \\
Recidivism & Pearson Correlation & $.669\left(^{* *}\right)$ & 1 \\
& Sig. (2-tailed) & .000 & \\
& $\mathrm{~N}$ & 329 & \\
\hline
\end{tabular}

** Correlation is significant at the 0.01 level (2-tailed).

Source: Field data, $(2018)$

Study findings in table 2 reveal a significant relationship between individual characteristics and recidivism among released prisoners in Kakamega County $(\mathrm{r}=0.669 ; \mathrm{P}<0.01)$. This implies that individual characteristics of respondents have a significant influence on repeat offending among released inmates in Kakamega County. The null hypothesis that states that there is no significant relationship between individual characteristics and recidivism among released prisoners is therefore rejected at the level of significance of 0.01 and its alternative which states that there is a significant relationship between individual characteristics and recidivism among released prisoners adopted.

To determine the differences in the extent of the influence of individual characteristics on recidivism, measures of dispersion and variability are computed and findings presented in table 3.

Table 3: Individual characteristics and their influence on recidivism

\begin{tabular}{llll}
\hline Fear type & Mean & Standard Deviation & Standard Error of Mean \\
\hline Gender & 1.39 & .3591 & .04541 \\
Age & 1.37 & .3671 & .04356 \\
Offence Type & 1.31 & .3743 & .04691 \\
Number of Convictions & 1.04 & .3975 & .04591 \\
Period Between Incarcerations & 1.02 & .4167 & .03444 \\
Type of Prison Sentence & 1.18 & .4322 & .03549 \\
& & & .03298
\end{tabular}

Source: Field data, (2018)

Study findings in table 3 reveal that the mean for gender is the highest, namely 1.39. This implies that gender is the single individual characteristic with the highest influence on recidivism. There is a significantly higher number of male recidivists compared to incarcerated male offenders as compared to female recidivists as compared to incarcerated female offenders.

The age of respondents has the second-highest influence on recidivism with a mean of 1.37. This also reflects the age differences among recidivists, since there are more youthful offenders in prison as compared to aged or older offenders.

Offence type has a mean of 1.31 which points to the influence of offence type to recidivism. Offences against property are more prevalent among sampled recidivists as compared to offences against persons. Drug and substance abuse has a mean of 1.27 implying that even though there are recidivists who have committed offences related to drug and substance abuse, the rate of recidivism in this category of offence is not prevalent. Prison sentence as long, medium or short has a mean of 1.18 implying that the length of a prison sentence has significantly minimal influence on recidivism. 
Given the small differences in the means for the various individual characteristics in explaining recidivism, there is a need to establish whether these differences in the means are statistically significant. In this regard, a onesample independent t-test for equality of means has been computed at 0.05 level of significance and findings presented in table 4.

Table 4: T-Test for equality of means

\begin{tabular}{|l|l|l|l|l|l|l|l|}
\hline & \multicolumn{2}{|l|}{$\begin{array}{l}\text { Levene's Test for } \\
\text { Equality of Variances }\end{array}$} & \multicolumn{2}{l|}{ t-test for Equality of Means } \\
& $\mathrm{F}$ & Sig. & $\mathrm{T}$ & $\mathrm{df}$ & $\begin{array}{l}\text { Sig. (2- } \\
\text { tailed) }\end{array}$ & $\begin{array}{l}\text { Mean Difference } \\
\text { Error } \\
\text { Difference }\end{array}$ \\
\hline $\begin{array}{l}\text { Equal Variances } \\
\text { Assumed }\end{array}$ & 0.371 & .508 & 3.308 & 28 & .027 & 2.945 & 1.374 \\
\hline $\begin{array}{l}\text { Equal Variances } \\
\text { not Assumed }\end{array}$ & & & 3.009 & 27.417 & .042 & 3.071 & 1.399 \\
\hline
\end{tabular}

$t$-critical $(d f=2,28, t=2.99, p \leq 0.05) ; t$-calculated $(d f=2,28, t=3.308, p=0.027)$

Source: Field data, (2018)

Study findings in table 4 indicate that there is a statistically significant difference in the mean between the various individual characteristics as indicators of recidivism among released prisoners in Kakamega County $(\mathrm{t}=3.308, \mathrm{P}<0.05, \mathrm{df}=2,28)$. This is further shown where the critical value of $\mathrm{t}(2.99)$ is less than the calculated value of $\mathrm{t}(3.308)$.

1.8.2.1 Regression analysis of offender characteristics and recidivism

Research data on offender characteristics has been subjected to regression analysis to predict recidivism amongst offenders released from prisons within Kakamega County and findings presented in table 5.

Table 5: Model Summary for Offender Characteristics and Recidivism

\begin{tabular}{llllll}
\hline Model & $\mathrm{R}$ & $\mathrm{R}$ Square & $\begin{array}{l}\text { Adjusted } \mathrm{R} \\
\text { Square }\end{array}$ & $\begin{array}{l}\text { Std. Error of the } \\
\text { Estimate }\end{array}$ & Durbin-Watson \\
\hline 1 & $.478^{\mathrm{a}}$ & .237 & .234 & .78652 & 1.775 \\
\hline
\end{tabular}

a. Predictors: (Constant), Offender Characteristics

b. Dependent Variable: Recidivism

Study findings from regression analysis where offender characteristics are used as predictors of recidivism reveal an $\mathrm{R}$ squared value of 0.237 implying that offender characteristics account for $23.7 \%$ of the variance in recidivism among sampled offenders.

\subsubsection{Interviews with Probation and Prison Officers}

Interview guides were used to seek the opinion of Probation Officers and Prison Officers on the relationship between offender characteristics and recidivism. The aim is to assess whether the characteristics exhibited by offenders would explain the possibility of repeat offending. The majority of the interviewed Probation Officers $(69.4 \%)$ were of the view that offender characteristics have a significant influence on recidivism among released prisoners in Kakamega County.

The majority of the interviewed Probation Officers (57.1\%) were of the general view that more youthful offenders were more likely to breach Probation Orders as compared to older offenders. Probation Officers were also of the view that male offenders were highly likely to breach the conditions of the Probation Orders as compared to their female counterparts. In all cases where an offender breaches Probation Orders, they get arrested for the breach of the Order and an alternative sentence is meted out for them hence making them repeat offenders. In Kenya, in the year 2017, there were 16371 male recidivists out of an estimated 52000 male 
prisoners and 1453 female recidivists out of an estimated 5000 female prisoners (Kenya National Bureau of Statistics, 2018:267).

Most of the interviewed Probation Officers (52.9\%) also indicated that the type of offence committed had a significant influence on recidivism. Officers who were interviewed noted that offenders who had committed crimes that were utilitarian in nature such as theft, burglary, etc were more likely to repeat similar offences upon release from prisons or more severe offences such as attempted robbery or robbery. This corroborates with the Kenya Economic Survey (2018:270), which reports that the following crimes were committed by convicted offenders in 2017

- $\quad$ Order and administration of lawful authority 8505

- $\quad$ Injurious to public 3325

- $\quad$ Against person 6529

- $\quad$ Related to property 8306

- $\quad$ Attempts and conspiracies 1633

- $\quad$ Employment 4262

- $\quad$ Trade in illegal liquor 26024

- $\quad$ Drug-related 5397

- $\quad$ Other cases 1419

The majority of interviewed Prison Officers (72.3\%) were of the view that offenders sentenced for petty offences were highly likely to recidivate due to the nature of the short sentences that they received, with most of them ranging from one week to six months. During this period, offenders are not likely to undergo any tangible rehabilitation programme. Further still, offenders with drug-related offences or those with a history of narcotic drug use were more likely to engage in repeat offending given the negative influence of the drug and also given the peer group associations that come with drug use. From the above response from correctional officers, it is evident that individual characteristics of an offender have a significant role in determining recidivism among released prisoners.

\subsubsection{Focus group interviews}

The general thread emanating from the focus group discussions seems to allude to mixed findings for different offenders. Some family and community members $(49.8 \%)$ were of the view that the offenders have improved in character after incarceration while others $(50.2 \%)$ were of the view that offenders have worsened in character. Other community members $(2.7 \%)$ opined that there was no significant change in the character of the offenders before and after incarceration or placement on probation.

Focus group discussions with two ex-offenders, four family members of an ex-offender and a victim of crime, four community members as well as local administration, and a religious leader presented mixed feelings regarding the potential of offenders to engage in repeat offending. Even though family members of ex-offenders were optimistic that ex-offenders would eventually change and become law-abiding, community members and local administrators held divergent views regarding the possibility of ex-offenders reforming after a period of incarceration.

The above discussions allude to different viewpoints for different categories of community members of recidivists. In as much as close relatives to recidivists might want to portray offenders as being capable of reforming and become good citizens, community members seem to paint offenders as people who cannot change and who should be suspected of any wrongdoing in the community when there is nobody else to suspect.

\subsection{Recommendations}

This section presents the recommendations of the study based on the findings of the investigation. 
Offender characteristics and recidivism

The study reveals a significant relationship between offender characteristics and recidivism. From the study, it is recommended that treatment plans drawn by correctional officers should take into account the individual characteristics of released offenders since there is a strong association between individual characteristics of offenders and recidivism. The government should facilitate the correctional officers with the required resources to use the Actuarial Risk Assessment model. The model is applied to released offenders to predict the future probability of recidivism (Robinson \& Crow, 2009: 91). This can be achieved through the application of the "Offenders Group Reconviction Scale" a windows based programme for use by correctional officers. This involves a database consisting of information about the demographic characteristics and offending histories of the offenders. The instrument provides an estimate expressed as a percentage of the statistical likelihood of reconviction within two years of release from custody (Robinson \& Crow, 2009: 91). The key variables that Offender Group Reconviction Scale considers in calculating the statistical likelihood of reconviction are

- Age;

- Gender;

- Offense type;

- Numbers of previous convictions; and

- Age at first conviction.

These are key constructs identified by the study to have a significant correlation on recidivism. The results obtained from the instrument can be used to come up with the necessary categorisation of offenders based on their risk levels of re-offending. Correctional officers' ability to classify offenders into "low-risk" and "highrisk" groups will enable them to develop offender treatment plans that are effective based on the risk levels of individual ex-offenders.

\section{Gender}

The study established that there is a significantly higher number of male recidivists compared to the total male prison population than that of female recidivists computed against the total female prisoners. From the study, it is recommended further investigations to establish the main causes of gender differences in re-offending. The study also recommends a gender-sensitive treatment approach to the rehabilitation of offenders. This is because the current generalised approach to the treatment of offenders has been pointed out to be ineffective in addressing rehabilitation needs among male recidivists.

\section{Age at first conviction}

The study reveals a significant relationship between age at first conviction and recidivism. Because incarceration is particularly prevalent among youthful offenders as found by the study, the impact on their future adult life will be more pronounced since they are wasting the energetic part of their life in prison. It is recommended that that the government and other stakeholders come up with policies and programmes aimed at specifically addressing factors influencing increased youth reoffending. In addition, extensive post-release treatment and after-care services for youthful offenders need to be developed, implemented, monitored and regular assessments are done to review the progress made in reducing recidivism.

\section{Offence type}

Offences against property and drug-related were more prevalent among recidivists. It is recommended that the offenders should take individual responsibility and make a conscious decision to desist from crime and drug abuse. In addition, there is the need for correctional officers to introduce evidence-based treatment of offenders with a specific focus on those convicted against property and drug-related offences as a way to mitigate against the prevalence of the two forms of crime amongst released offenders.

\section{Drugs and substance abuse}

The need for alcohol and drug treatment should be addressed amongst released offenders. Drug and alcohol abuse is implicated in the crimes and incarceration of the majority of prisoners. There's a strong link between possession and sales of drugs and offences committed by ex-offenders to obtain money to purchase drugs e.g. burglary and robbery. Prison-based and community-based drug treatment programmes should be emphasised in sustaining sobriety. Ex-offenders should be encouraged to form self-help groups to help them with long-term social support that aids them in successful reintegration into the community.

\section{Length of the prison sentence}

Since the investigation did not find a significant influence of the length of a prison sentence on recidivism, it is recommended that prison-based rehabilitation should take into account the imprisonment duration of offenders. 
This will help all offenders regardless of the length of the sentence. To mitigate high-risk offenders who serve long sentences and in turn face greater reentry challenges, the study recommends that treatment plans for longterm offenders should focus on transitional challenges that accompany prolonged prison sentences.

\section{List of references}

Abotchie, C. (2008). Treatment of Criminals and Crime Prevention in Ghana, Accra:

Abrifor, A., Atere, A. \& Muoghalu, C. (2012). Gender differences, trend and pattern inmates in selected Nigerian prisons. European Scientific No.24 ISSN: 1857-7881: 25-44.

Agnew, R. (2006). Pressured into crime: An overview of general strain theory. Los

Agnew, R., Brezina, T., Wright, \& Cullen, F. T. (2002). Strain, personality traits, and Extending general strain theory. Criminology, 40(1), 43-72.

Akers, R.L. \& Sellers, W.G. (2009). Social learning theory. In J. M. Miller (Ed.), $21^{\text {st }}$ A reference handbook. Thousand Oaks, CA: Sage.

Athens, L.H. (1994). The Creation of Dangerous Violent Criminals. Urbana: University of Illinois Press. Olympia: Washington State Institute for Public Policy.

Bachman., R. and Schutt., R. (2017). The Practice of Research in Criminology and Criminal Justice. Sixth Edition. London: Sage publications.

Bales, W.D. \& Mears, D.P. (2008). Inmate social ties and the transition to society: Does visitation reduce recidivism? Journal of Research in Crime and Delinquency, Vol.45 (No.3), pp.287-321.

Bandura, A. (1977). Social Learning Theory. Englewood Cliffs. NJ: Prentice-Hall.

Barnett, R. and Hagel, J. (1977). Assessing the criminal: restitution, retribution and the Massachusetts: Ballinger Publishing Group.

Becker, H. (1963). Outsiders; studies in the sociology of deviance. London: Free Press

Benda, B.B. (2005). Gender Differences in Life-Course Theory of Recidivism: A International Journal of Offender Therapy and Comparative Criminology, pp. 325-342.

Blumstein, A., Jacqueline, C., Jeffrey, A.R. \& Charity, A.V. (1986). Criminal Career and Career Criminals. Washington D.C.: National Academy Press.

Borzycki, M. \& Makkai., T. (2007). Prisoner Reintegration Post-release. Canberra: Criminology.

Braman, D. (2004). Doing time on the outside: Incarceration and family life in urban University of Michigan Press.

Brazzell, D. (2007). Informing and Engaging Communities through Reentry Mapping. Justice Policy Center, Urban Institute.

Broadhurst, R. \& Maller, R.A. (1991). Sex offending and recidivism. Perth: University Crime Research Centre.

Chesney-Lind, M. (2002). Imprisoning women: The unintended victims of mass imprisonment. In M. Mauer, ed. And M.Chesney-Lind (Eds.), Invisible punishment: The collateral consequences of mass imprisonment (79-94). NewYork: The Free Press.

Chiricos, T., Barrick, K., Bales, W. \& Bontrager, S. (2007). The labeling of convicted felons and its consequences for recidivism. Criminology, Vol.45 (No.3), 547-

DeLeon, G. (2000). The therapeutic community: Theory, model, and method. New Desistance Toward a Theory of Cognitive Transformation. 990-1064.

Duguid, S. (2000). Can Prisons Work? The Prisoner as Object and Subject in Modern University of Toronto Press.

Duwe, G. (2010). "Evaluating the Minnesota Comprehensive Offender Reentry Plan from a Randomized Experiment”. Justice Quarterly, 29 (3), 347-383.

Duwe, G. (2010). Prison-Based Chemical Dependency Treatment in An Evaluation Experimental Criminology, 6 (1), 57-81.

Duwe, G. (2010). Prison-Based Chemical Dependency Treatment: An Evaluation Experimental Criminology, 6 (1), 57-81.

Farrall, S. (2004). Rethinking What Works with Offenders: Probation, Social Context Crime. Cullompton, UK: Willan.
Australian Institute of

America. Ann Arbor:

Washington (D.C.):

of Western Australian

York: Springer

of Sociology, 107,

Corrections. Toronto:

(MCORP): Result

Outcome. Journal of

Outcome. Journal of

and Desistance from 
Farrington, D.P. (2005). “The Integrated Cognitive Antisocial Potential Theory.” In Farrington, D.P. (ed.), Integrated Developmental and Life-course Theories of Offending (pp.73-92). New Brunswick, NJ: Transaction.

Fergusson, D.M. \& Horwood, L.J. (2000). Alcohol abuse and crime: A fixed-effects regression analysis. Addiction, 95, 1525-1536.

Garvin, E.C., Cannuscio, C.C. \& Branas, C.C. (2013). Greening vacant lots to reduce violent crime: A randomised controlled trial. InjuryPrevention,19, 198-203.

Glaze, L.E. \& Bonczar, T.P. (2007). Probation and parole in the United States. Bureau of Justice Statistics Bulletin. Washington, DC: U.S. Department of Justice.

Glaze, L.E. \& Maruschak, L.M. (2008). Parents in prison and their minor children. Special report. Washington, DC: Bureau of Justice Statistics.

Graffam, J., Shinkfield, A., Lavelle, B. \& McPherson, B.W. (2004). Variables Affecting Successful Reintegration as Perceived by Offenders and Professionals. Journal of Offender Rehabilitation, 40, $(1 / 2), 147-171$

Grant, B.A. et. al. (2003). Report on the priorities of the International Experts Forum. Montague, $\quad$ PEI: Addictions Research Centre (in press).

Griffith, C.T. (2012). Canadian Corrections. Ontario: Nelson Education Ltd.

Griffiths, C.T. (2004). Canadian Corrections. $2^{\text {nd }}$ edition.Toronto: Thomson Nelson.

Grifiths, C.T. (2007). "The Social Reintegration of Offenders and Crime Prevention.” National Crime Prevention Centre: Ottawa.

Hagan, M. (2013). The Impact of Rehabilitation Programmes of the Nsawam Prison. Cambridge, $\quad$ MA: Cambridge University Press.

Hanson, R.K. \& Bussiere, M.T. (1998). Predicting relapse: A meta-analysis of sexual offender recidivism studies. Journal of Consulting and Clinical Psychology, $\quad 66,348-362$.

Hanson, R.K. \& Morton-Bourgon, K.E. (2005). The characteristics of persistent sexual offenders: A metaanalysis of recidivism studies. Journal of Consulting and Clinical Psychology, 73, 1154-1163.

Hanson, R.K., Broom, I. \& Stephenson, M. (2004). Evaluating community sex offender treatment programmes: A12-year follow-up of 724 offenders. Canadian Journal of $\quad$ Behavioural Science, 36, 87-96.

Harlow, C.W. (1999). Prior abuse reported by inmates and probationers. Washington, DC: Bureau of Justice Statistics, U.S. Department of Justice.

Harlow, C.W. (2003). Education and correctional populations. Washington, DC: U.S. Department of Justice, Office of Justice Programmes.

Hassin, Y. (1989). Notes on the rehabilitation of released offenders in the community. Studies in Criminology, Vol. 17 (No. 1), pp. 43-49.

Horney, J., Osgood, D.W. \& Marshall, I.H. (1995). Criminal careers in the short-term: Intra-individual variability in crime and its relation to local life circumstances. American Sociological Review, Vol.60 (No.5), 655-673.

Klein, S.P. \& Caggiano, M. N. (1986). The prevalence, predictability and policy implications of recidivism. USA: Bureau of Justice Statistics.

Knight, K., Simpson, D. D. \& Hiller, M. L. (1999). Three-year re-incarceration outcomes for in-prison therapeutic community treatment in Texas. The Prison Journal, 79, 337-351.

Koehler, J. A., Loser, F. \& Humphreys, D. K. (2010). A Systematic Review and Meta analysis on the Effects of Young Offender Treatment Programmes in Europe. Journal of Experimental Criminology, 9, 19-43.

Kothari., R. (2004). Research methodology: Methods \& techniques ( $2^{\text {nd }}$ Revised Edition). $\quad$ New Delhi: New age international publishers.

Kurlychek, M. C., Brame, R. \& Bushway. S. D. (2006). Scarlet letters and recidivism: does an old criminal record predict future offending? Criminology and Public Policy, 5, 483-504.

Kyvsgaard, B. (1990). Life on the bottom. The living conditions of law-breakers. Scandinavian Criminal Policy, 6, 68-79.

Lambrick, F. \& Glaser, W. (2004). Sex offenders with an intellectual disability. Sexual Abuse: A Journal of Research and Treatment, 16, 381-392.

Laub, J.H. \& Sampson, R.J. (2003). Shared beginnings, divergent lives: Delinquent $\quad$ boys to age 70. Cambridge, MA: Harvard University Press.

Laub, J.H., Nagin, D.S. \& Sampson, R.J. (1998). Trajectories of change in criminal offending: Good marriages and the desistance process. American Sociological Review, vol.63 (No.2), pp. 225-238. 
LaVigne, N.G., Visher, C. \& Castro, J. (2004). Chicago Prisoners' Experience Returning Home. Washington, DC: Urban Institute.

Law, M. A. (2004). Federally Sentenced Women in the Community: Dynamic risk Predictors. Criminal Justice and Behaviour, 2015, Vol. 42, No. 5, May 2015, 457-480.

LeBel, T.P., Burnett, R., Maruna, S. \& Bushway, S. (2008). 'The "chicken and egg” of subjective and social factors in desistance from crime', European Journal of Criminology, 5(2): 130-159.

Leverentz, A. (2006). The love of a good man? Romantic relationships as a source of support or hindrance for female ex-offenders. Journal of Research in Crime and Delinquency, Vol.43 (No.4), pp.459488.

Lievore, D. (2004). "Recidivism of Sexual Assault Offenders: Rates, Risk Factors, and Treatment Efficacy." A Report Prepared for the Office of the Status of Women. Canberra: Australian Institute of Criminology.

Lior, G. \& Hung-En, S. (2011). Rethinking Corrections: Rehabilitation, Reentry, and Reintegration. California: Sage Publications.

Lipsey, M. W. (1999). Can Intervention Rehabilitate Serious Delinquents? Annals of the American Academy of Political and Social Science, 564,142-166.

Lipton, D. S., Pearson, F. S., Cleland, C. M. \& Yee, D. (2002). The effects of therapeutic communities and milieu therapy on recidivism. Etobicoke: John Wiley Canada.

Lopoo, L., \& Western, B. (2005). Incarceration and the Formation and Stability of Marital Unions. Journal of Marriage and Family, 67,721-734.

Losel, F., \& Schmucker, M. (2005). The effectiveness of treatment for sexual offenders: A comprehensive meta-analysis. Journal of Experimental Criminology, 1, 117-146.

Loucks, N. (2002). Recidivism amongst serious violent and sexual offenders. Edinburgh: Scottish Executive Social Research.

Lynch, J. P. \& Sabol, W. J. (2001). Prisoner Re-entry in Perspective. Washington, D.C: Urban Institute.

MacKenzie, D. L. (2006). What Works in Corrections: Reducing the Criminal Activities of Offenders and Delinquents. New York: Cambridge University Press.

Malott, M., \& Fromader, A. (2010). "Male Inmate Perspective on Reducing Recidivism Rates Through PostIncarceration Resources". Journal of Criminology.

Maltz, M. (1984) Recidivism. Maltz Publishers, New York.

Maltz, M. (2001). Recidivism. Florida: Academic Press.

Maltz, M. D. (2001). Recidivism. Florida: AcademicPress.

Marlow, C. R. (2005). Research and Methods for the Generalist Social Worker (4th $\quad$ ed.) Belmont, CA: Thomas Learning/Brookes Cole.

Marques, J.K., Wiederanders, M., Day, D. M., Nelson, C. \& van Ommeren, A. (2005). Effects of a relapse prevention programme on sexual recidivism. A Journal of Research and Treatment, 17, 79-107.

Marshall, C., \& Rossman, G. B. (2006). Designing Qualitative Research (4 ${ }^{\text {th }}$ ed.). $\quad$ Thousand Oaks, CA: Sage.

Marshall, W. L., Ward, T., Mann, R. E., Moulden, H., Fernandez, Y. M. \& Serran, G. (2005). Working positively with sexual offenders: Maximizing the effectiveness of treatment. Journal of Interpersonal Violence, 20, 1096-1114.

Martinez, D. J. \& Abrams, L. S. (2013). Informal Social Support Among Returning Young Offenders: A Meta-synthesis of the Literature. International Journal of Offender Therapy and Comparative Criminology, 57 (2), 169-190.

Martinson, R. (1974). What Works? Questions and Answers About Prison Reform”. The Public Interest, $35,22-54$.

Maruna, S. \& LeBel, T. (2002). "Revisiting Ex-prisoner Re-entry: A Buzz word in $\quad$ Search of a Narrative.'In Griffiths (2007). Social Reintegration of Offenders and Crime Prevention. National Crime Prevention Centre: Ottawa.

Maruna, S., Immarigeon, R. \& Lebel, T. P. (2001). Making good: How ex-convicts $\quad$ reform and rebuild their lives. Washington, DC: American PsychologicalAssociation.

Maxfield., G \& Babbie (2015). Research methods for criminal justice and criminology. Seventh Edition. California: Cengage Learning Press.

McConaghy, N. (1999). Methodological issues concerning evaluation of treatment for sexual offenders: Randomization, treatment dropouts, untreated controls, and within treatment studies. Sexual Abuse: A Journal of Research and Treatment, 11,183-194. 
Merton, R. K. (1958). Social Structure and Anomie. In Haralambos, M., and Holborn, Themes and Perspectives, London: Collins Educational.

Miller, W. R. \& Rollnick, S. (Eds.). (2002). Motivational interviewing: Preparing people for change (2nded.). New York: Guilford.

Ministry of Justice Analytical Series in the UK (2013). Transforming Rehabilitation: A Summary of Evidence on Reducing Re-offending. Retrieved on $2^{\text {nd }}$ July, $2016 \quad$ from www.gov.uk/government/uploads/attachment.

Ministry of Justice Analytical Series in the UK. (2012). Transforming Rehabilitation: A Summary of Evidence on Reducing Re-offending. Retrieved on 2nd July, 2018 from www.gov.uk/government/uploads/attachment.

Ministry of Justice, England. (2011). Report on adult reconviction from the 2009 cohort for England and Wales. London. Government printers.

Ministry of Justice's report on adult reconviction from the 2009 cohort for England and Wales (2011).

Ministry of Planning, National Development \& Vision 2030, Kenya. (2007). Vision Government Printers.

Mugenda, O. \& Mugenda, A. (2003). Research methods: quantitative and qualitative African Centre for Technology Studies.

Mukamal, D. (2000). Confronting the Employment Barriers of Criminal Records: Legal and Practical Strategies. Journal of Poverty Law and Policy.

Mumola, C. J. (1999). Substance Abuse and Treatment, State and Federal Prisoners. National Institute of Justice.

Nabi, R. L. (2003). "Feeling"' resistance: Exploring the role of emotionally evocative visuals in inducing inoculation. Media Psychology, 5, 199-223.

Nally, J. M., Lockwood, S. R., Ho, T. \& Knutson, K. (2012). The post-release employment and recidivism among different types of offenders with a different level of education: A 5-year follow-up study in Indiana. Justice Policy Journal, 9(1)

Naser, R. L. \& LaVigne, N. G. (2006). "Family support in the prisoner reentry process: Expectations and realities". Journal of Offender Rehabilitation, 43, 93-106.

Nelson, M. \& Van Ommeren. (2005). The First Month Out: Post-Incarceration Experiences in New York City. New York, NY: Vera Institute of Justice.

Newing., H. (2011). Conducting Research in Conservation: Social science methods and practice. London: Routledge Publishers.

Ohio Department of Rehabilitation and Corrections. (2010). What Works? General Principles, Characteristics, and Examples of Effective Programmes.

Olusanya, O. \& Gau, J. M. (2012). Race, neighbourhood context and risk prediction. Criminal Justice Studies,25,159-175.

Oruta, E., Omosa, N. \& Lusire, L. (2017). The role of prison experience on recidivism in Kakamega County, Kenya. Journal of Public Policy and Administration Research. ISSN２225-0972 (Online) Vol.7, No.5, 2017

Owens, J. (2009). "Social Symbols, Stigma, and the Labour Market Experiences of Former Prisoners". Journal of Correctional Education, 60 (4), 316-342.

Pager, D. (2003). "The Mark of a Criminal Record. "American Journal of Sociology,

Patterson, G. R. (1995). Depression and Aggression in Family Interaction. Hillsdale, Erlbaum Associates.

Petersilia, J. (2003). When Prisoners Come Home: Parole and Prisoner Re-entry, New York: $\quad$ Oxford University Press.

Pfau, M., Compton, J., Parker, K. A., An, C., Wittenberg, E. M., Ferguson, M., Horton, H. \& Malyshev, Y. (2010). The conundrum of the timing of counter arguing effects in resistance: Strategies to boost the persistence of counter arguing output. Communication Quarterly.

Reitzel, L. R. (2006). Sexual offender update: Public policy. The Correctional Psychologist, 38,1-4.

Republic of Kenya (2012). Department of Correctional Services: Prisons Act. Nairobi: Government Press.

Republic of Kenya. (2017). Department of Correctional Services: The Prisons Amendment Act No. 11 of 2017. Nairobi: Government Printers.

Republic of Kenya. (2017). Department of Correctional Services: The Probation of $\quad$ Offenders Act No. 11 of 2017. Nairobi: Government Printers. 
Rice, M. E. \& Harris, G. T. (2003). The size and sign of treatment effects in sex offender therapy. Annals of the New York Academy of Sciences, 989, 428- 440.

Richie, B. (2001). Challenges incarcerated women face as they return to their communities: Findings from life history interviews. Crime and Delinquency, Vol. 7 (No.3), pp.368-389.

Roberts, A. R., Zgoba, K. M. \& Shahidular, S. M. (2007). 'Recidivism among four types of homicide in New Jersey', Aggression \& Violent Behaviour. 12: 294-507.

Rutter, M. (1987). Psychosocial resilience and protective mechanisms. American Journal of Orthopsychiatry.

Ryan, J. P., \& Yang, H. Y. (2005). Family contact and recidivism: A longitudinal study of adjudicated delinquents in residential care. Journal of Social Work Research.

Sabol W. J. \& Couture, H. (2008). Prison inmates at midyear 2007 (No. NCJ 221944). Washington, DC: Bureau of Justice Statistics.

Sampson, R. J. \& Laub, J. H. (1993). Crime in the making: Pathways and turning points through life. Cambridge, MA: Harvard University Press.

Scott, G. (2004). "It's a sucker's outfit": How urban gangs enable and impede thereintegration of ex-convicts. Ethnography, Vol.5 (No.1), pp.107-140.

Seal, D. W., Eldrige, G. D., Kacanek, D., Binson, D. \& Macgowan, R. J. (2007). A longitudinal, qualitative analysis of the context of substance use and sexual behaviour among 18 to 29-year-old men after their release from prison. Social Science and Medicine, Vol. 65 (No.11), pp.2394-2406.

Seligman, M. P., Linley, P. A. \& Joseph, S. (2004). Positive psychology in practice. Hoboken, JohnWiley.

Shapiro, C. \& Schwartz, M. (2001). Coming Home: Building on Family Connections. Corrections Management Quarterly, 5(3), 52-61.

Sheldon, K. M., Williams, G. \& Joiner, T. E. (2003). Self-determination theory in the clinic: Motivating physical and mental health. New Haven, CT: Yale University Press.

Sherman, L. W. (1993). Deviance, Deterrence, and Irrelevance: A Theory of the Criminal Sanction. Journal of Research in Crime and Delinquency, 30, 445-473.

Simpson, D. D. (2004). A conceptual framework for drug treatment process and outcomes. Journal of Substance Abuse Treatment, 27, 99-121.

Slocum, Lee Ann, Sally S. Simpson, and Douglas A. Smith. (2005). Strained lives and crime: Examining intra-individual variation in strain and offending in a sample of incarcerated women. Criminology 43(4)

Solomon, A. L., Johnson, K. D., Travis, J. \& Mcbride, E. C. (2004). From prison to $\quad$ work: The employment dimensions of prisoner reentry. A report of the Reentry Round table. Washington, DC: The Urban Institute.

Soothill, K., Ackerley, E., \& Francis, B. (2004). The criminal careers of arsonists. Medicine, Science and the Law. 44 (1): 27-40

Sounders, Lewis \& Thornhill, (2009). Research methods for business students. London: Prentice-Hall Thousand Oaks, CA: Sage.

Southey, Braybrook \& Spier. (1994). Rape Recidivism and Sexual Violation. Department of Justice.

Soyombo, O. (2009). Sociology and Crime Control: That We May Live in Peace. An Inaugural Lecture Delivered at the University of Lagos. Lagos: University of Lagos Press.

Stevens, P., \& Ward, C. (1997). College education and recidivism: Educating criminals is meritorious. Journal of Correctional Education, 48, 106-111.

Sykes, G. M. (1958). The Society of Captives: A Study of a Maximum Security Prison, Princeton. $\quad$ NJ: Princeton University Press.

Taxman, F. S., \& Bouffard, J. A. (2002). Assessing therapeutic integrity in modified therapeutic communities for drug-involved offenders. The Prison Journal, 82,189- 212.

Tibbetts, S. G., \& Hemmens, C. (2015). Criminological theory: a text/reader. Los

Tillyer, M.S., \& Vose, B. (2011). Social ecology, individual risk, and recidivism: A of main and moderating influences. Journal of $\quad$ Criminal Justice, 39,452-459.

Travis, J. (2005). But they all come back: Facing the challenges of prisoner reentry. Washington, DC: The Urban Institute Press.

Travis, J., A. Solomon, and Waul, M. (2001). From Prison to Home: The Dimensions and Consequences of Prisoner Reentry. Washington D.C.: The Urban Institute.

Angeles: SAGE.

multilevel examination 
Travis, J., Solomon, A., \& Waul, M. (2001). From Prison to Home: The Dimensions and Consequences of Prisoner Reentry. Washington D.C.: The Urban Institute.

Uggen, C. (1999). Ex-offenders and the conformist alternative: A job quality model of work and crime. Social Problems, Vol.46 (No.1), pp.127-151.

Uggen, C. (2000). Work as a turning point in the life course of criminals: A duration model of age, employment, and recidivism. American Sociological Review, Vol.65 (No.4), pp. 529-546.

Uggen, C., \& Thompson, M. (2003). The socio-economic determinants of ill-gotten gains: Withinperson changes in drug use and illegal earnings. American Journal of Sociology, Vol.109 (No.1), pp.146.

Ullman, W. R., \& Bodaken, E. M. (1975). Inducing resistance to persuasive attack: A test of two strategies of communication. Western Speech Communication, 39, 240-248.

VandeKoehler, L. M., Leenarts, L. E. W., Born, M. P. \& Oosterveld, P. (2012). Reevaluating Interracter Reliability in Offender Risk Assessment. Crime and Delinquency, 58(1), 147-146.

Vanderstoep., S. \& Johnson., D. (2009). Research methods for everyday life: Blending qualitative $\quad$ and quantitative approaches. San Francisco: John Wiley \& Sons

Verbrugge, P., Nunes, K., Johnson, S. \& Taylor, K. (2002). Predictors of Revocation of Conditional release among Substance Abusing Women Offenders. Ottawa, Ontario: Correctional Service of Canada.

Vick, K. (2009). Sex offender laws are leading to homelessness. Boston Globe.

Villetaz, P., Gillieron, G., \& Killars, M. (2006). The Effects on Re-offending of CustodialVersus Non-custodial Sanctions. Report for the National Council for Crime Prevention in Sweden.

Villetaz, P., Gillieron, G., \& Killars, M. (2006). The Effects on Re-offending of CustodialVersus Non-custodial Sanctions. Report for the National Council for Crime Prevention in Sweden.

Visher, C. A., \& Travis, J. (2003). The transition from Prison to Community: Understanding Individual Pathways. Annual Reviews Sociology, 29,89-113.

Visher, C. A., Sara, A., Sherril, D. \& Yahner, J. (2005). Employment After Prison: A Longitudinal Study of Former Prisoners. Justice Quarterly, 28(5), 699-718.

Visher, C., Debus, S., \& Yahner, J. (2008). Employment after prison: A longitudinal $\quad$ study of releases in three estates. Washington,DC:TheUrbanInstitute.

Visher, C., Kachnowski, V., LaVigne, N., \& Travis, J. (2004). Baltimore Prisoners' Experiences Returning Home. Washington, DC: The Urban Institute.

Walmsley, R. (2010). World prison population list. Institute for criminal policy research.

Walmsley, R. (2016). World prison population list. Institute for criminal policy research.

Ward, T. \& Steward, C. A. (2003). The Treatment of Sex Offenders: Risk Management and Good Lives. Professional Psychology: Research and Practice, 34, $353 \quad 360$.

Ward, T., \& Hudson, S. M. (1998). A model of the relapse process in sexual offenders. Journal of Interpersonal Violence, 13, 400-425.

Warr, M. (1998). Life-course Transitions and Desistance from Crime. Criminology, 36,183-216.

Webster, S. D. (2005). Pathways to sexual offense recidivism following treatment. Journal of Interpersonal Violence, 20, 1175-1196.

Western, B. (2007). Mass Imprisonment and Economic Inequality. Social Research: An Anternational Quarterly, 74(2), 509-532.

Wikoff, N., Morani, N. M., \& Linhorst, D. M. (2011). A Description of the Self-identified Needs, Service Expenditure and Social Outcome of Participants of Prison Reentry Programme. The Prison Journal, 4 (3), 399-435.

Wilkinson, J. (2005). Evaluating evidence for the effectiveness of the Reasoning and Rehabilitation programme. The Howard Journal, 44, 70-85

Wilson, D. B., Bouuffard, L. A. \& MacKenzie, D. L. (2005). A Quantitative Review of Structured, GroupOriented, Cognitive-Behavioural Programmes for Offenders. Criminal Justice and Behaviour, 32(2), 172-204.

Wilson, H., (2009). Curbing Recidivism in Our Society. Available at http://www.pioneerng.com/article.php?title=Curbing_Recidivism_In_Our_Soci et (accessed on $12^{\text {th }}$ December, 2016).

Wilson, J., \& Herrnstein, R. (1985). Encyclopedia of Criminological Theory: Sage.

Wilson, J., Picheca, J., \& Prinzo. (2005). Circles of Support \& Accountability: Engaging the community in sexual offender risk management. In: B.K. Schwartz (Ed.), The sexual offender, Vol. 5. New York, NY: Civic Research Institute. 
Wilson, J.Q., \& Kelling, G.L. (1982). Broken windows. Atlantic Monthly, 249, 29-38. 